Abstracta Iranica Abstracta Iranica

Revue bibliographique pour le domaine irano-aryen

Volume 25 | 2004

Comptes rendus des publications de 2002

\title{
« Zoroastre dans l'histoire ou dans le mythe ? À propos du dernier livre de Gherardo Gnoli ».JA 289/2, (2001), pp. 171-184.
}

Rémy Boucharlat

\section{(2) OpenEdition}

Journals

Édition électronique

URL : http://journals.openedition.org/abstractairanica/4785

DOI : 10.4000/abstractairanica.4785

ISSN : 1961-960X

Éditeur :

CNRS (UMR 7528 Mondes iraniens et indiens), Éditions de l'IFRI

\section{Édition imprimée}

Date de publication : 15 mai 2004

ISSN : 0240-8910

Référence électronique

Rémy Boucharlat, « "Zoroastre dans l'histoire ou dans le mythe ? À propos du dernier livre de Gherardo Gnoli ». JA 289/2, (2001), pp. 171-184. », Abstracta Iranica [En ligne], Volume 25 | 2004, document 218, mis en ligne le 15 mars 2006, consulté le 25 septembre 2020. URL : http://

journals.openedition.org/abstractairanica/4785; DOI : https://doi.org/10.4000/abstractairanica.4785

Ce document a été généré automatiquement le 25 septembre 2020.

Tous droits réservés 
« Zoroastre dans l'histoire ou dans le mythe ? À propos du dernier livre de Gherardo Gnoli ». JA 289/2, (2001), pp. 171-184.

\author{
Rémy Boucharlat
}

Dans ce « review article » du livre de Gh. Gnoli, Zoroaster in History, 2000, l'A. annonce d'emblée sa position, opposée à celle de Gnoli (et de Shahbazi, c.r. $n^{\circ} 220$ ) puisqu'il doute de l'historicité de Zoroastre, mais non de celle de la diffusion des textes avestiques dès la fin $\mathrm{du} 4^{\mathrm{e}} \mathrm{s}$. avant $\mathrm{J}$.-C., diffusion qu'indiquent de fréquentes attestations. Il démonte ensuite la date traditionnelle « 258 ans avant Alexandre » qui relève de la mythologie mais non de l'histoire et récuse la valeur historique du fameux « 6000 ans avant l'expédition de Xerxès contre la Grèce » pour la vie de Zoroastre.

\title{
INDEX
}

Thèmes : 6.1. Zoroastrisme

\section{AUTEURS}

RÉMY BOUCHARLAT

CNRS - Lyon 